\title{
Use of local rice cultivars as additional differentials to identify pathotypes of Pyricularia oryzae
}

\author{
Gisele Barata da Silva ('); Leila Garcês de Araújo (2); Valácia Lemes da Silva Lobo (3); Anne \\ Sitarama Prabhu ( $\left(^{3}\right)$; Marcela Cristiane Ferreira Rêgo (1); Eduardo Tavares Paes ( ${ }^{4}$ ); Marta Cristina \\ Corsi de Filippi $\left(3^{*}\right)$ \\ (') Universidade Federal Rural da Amazônia (UFRA), Laboratório de Proteção de Plantas, 66077-901 Belém (PA), Brasil. \\ (2) Universidade Federal de Goiás, Instituto de Ciências Biológicas, ICB-I, 74001-970 Goiânia (GO), Brasil. \\ (3) Embrapa Arroz e Feijão, Caixa Postal 179, 75375-000 Santo Antônio de Goiás (GO), Brasil. \\ (4) UFRA, Instituto Sócio Ambiental e Recursos Hídricos, 66077-901 Belém (PA), Brasil. \\ (*) Corresponding author: cristina@cnpaf.embrapa.br
}

Received: December 14, 2010; Accepted: May 11, 2011

\begin{abstract}
Eight additional rice cultivars as differentials were selected to identify pathotypes occurring in the Tocantins State. They were BRS Jaburu, BRS Taim, BRS Biguá, BR IRGA-417, Epagri 109, Javaé, Metica-1 and Supremo. These differentials were used in addition to the international set to determine the pathogenic diversity of 193 Pyricularia oryzae isolates collected during 1994-2002 from irrigated rice cultivars. They were conserved in Pyricularia culture collection of Embrapa Rice and Bean Research center. From 193 P. oryzae isolates 38 pathotypes were identified based on leaf blast reactions of international set and 29 pathotypes based on these additional differentials. The predominant pathotypes (TI-1, TG-2, TD-15 and TF-2) were represented by $53 \%$ of the tested isolates. The major international pathotypes (IB-45, IB-41, II-1 and ID-13) were represented by $43 \%$ of the isolates tested. The virulence pattern of 28 isolates belonging to the pathotype IB- 45 was further differentiated into nine local pathotypes using additional set of differentials. The irrigated rice cultivars used as additional differentials serve as complementary set to identify pathotypes of interest for breeding blast resistant cultivars for Tocantins State.
\end{abstract}

Key words: Pyricularia grisea, rice leaf blast, physiologic races, Oryza sativa, virulence, resistance, differential varieties.

\section{Uso de cultivares local de arroz como diferenciadoras adicionais para identificar patótipos de Pyricularia oryzae}

\section{Resumo}

Um conjunto de oito cultivares diferenciadoras de arroz irrigado foi selecionado como diferenciadoras adicionais para identificar patótipos que ocorrem no Estado do Tocantins. As cultivares foram BRS Jaburu, BRS Taim, BRS Biguá, BR IRGA-417, Epagri 109, Javaé, Metica-1 e Supremo. A diversidade patogênica dos 193 isolados Pyricularia oryzae, coletados de cultivares de arroz irrigado durante 1994 a 2002 e conservados na coleção de cultura de Pyricularia do Centro de Pesquisa de Arroz e Feijão, foi avaliada utilizando oito cultivares diferenciadoras adicionais. Foram identificados 38 patótipos utilizando as cultivares diferenciadoras internacionais e 29 patótipos com as diferenciadoras adicionais. Os patótipos predominantes foram TI-1, TG-2, TD-15 e TF-2 representando 53\% do total de isolados testados. Com as diferenciadoras internacionais os predominantes foram IB-45, IB-41, II-1 e ID-13 representando 43\% dos isolados avaliados. O padrão de virulência dos 28 isolados pertencente ao patótipo IB-45 foi divido em nove patótipos quando foi utilizado as diferenciadoras adicionais. As cultivares de arroz irrigado usadas como diferenciadoras adicionais servem como um conjunto complementar para detectar patótipos de interesse para o melhoramento genético do Estado do Tocantins.

Palavras-chave: Pyricularia grisea, brusone, raça fisiológica, Oryza sativa, virulência, resistência, cultivares diferenciadoras.

\section{INTRODUCTION}

Tropical irrigated rice was planted in 54,680 ha during $2003 / 2004$, corresponding to nearly $50 \%$ of the total area of 162.135 ha in Tocantins in Brazil. (Levantamento Sistemático da Produçấo Agrícola, 2004).

The low yields of $4.5 \mathrm{t} \mathrm{ha}^{-1}$ are mainly attributed to rice blast caused by Pyricularia oryzae (=Magnaporthe oryzae B. Couch). In the early 1950's
LATTERell et al. (1954) first reported that the blast fungus is composed of pathotypes in the United States. Since then, several pathotypes have been reported in different countries using an international set of eight cultivars. Pathotypes identified based on the reaction of these differentials are called international pathotypes and are coded from IA to IH, followed by numerals to indicate pathotype numbers (AtKins et al., 1967; Ling and Ou, 1969). 
In Colombia, international pathotypes representing all nine pathotype groups were recovered from 15 rice cultivars (Correa-Victoria and Zeigler, 1993). Xia et al. (2000) reported the occurrence of two predominant pathotypes IB- 49 and IC-17 based on the analysis of 470 isolates from 18 farmers' fields in the State of Arkansas, U.S.A. On the other hand, MeKwatanakam et al. (2000) from Thailand and Thinlay et al. (2000) from Bhutan identified 175 and 53 pathotypes, respectively. In Brazil, the occurrence of pathotypes has been reported by several investigators in irrigated rice in different States (Filippi et al., 2002; Prabhu et al., 2002a). According to Filippi et al. (2002), 80\% of the isolates collected from four commercial farms in the State of Tocantins were of pathotype ID-14, indicating high cultivar specificity and narrow virulence diversity. Similarly, Prabhu et al. (2002a) found that pathotype IB-45 was represented by 47 of the 53 isolates collected from Epagri 108 and 109 in the epidemic year 1998-1999. Of 250 monosporic isolates collected from irrigated rice cultivars in the same state, Anjos et al. (2009) identified 45 pathotypes using international differentials indicating high variability.

In Japan, a set of nine differentials each with a known resistance gene was proposed (YAMAdA et al., 1976). Since these differentials are not isogenic lines, the presence of other unknown resistance genes may be present in cultivars and failed to describe adequately the diversity of pathotypes in the tropics (Ou, 1980). At the International Rice Research Institute (IRRI), a set of five near isogenic lines (NIL's) of cultivar CO39 was developed, with single major blast resistance gene, for characterizing pathogen population (MACKILl and Bonman, 1992). However, their value became limited because only few known genes are involved to describe the entire virulence spectrum of pathotypes. Also, the cultivar CO 39 used as recurrent parent posses other major resistance genes. To overcome this problem, Ling et al. (1995) developed a new series of near-isogenic lines (NIL's) utilizing a cultivar with a highly susceptible background such as LTH (Lijiangxintuanheigu) as recurrent parent and some Japanese differentials with known genes as donors. Later, KobaYAshi et al. (2007) developed the first set of monogenic lines (MLs) as international differential varieties which targeted a large number of resistance genes while harboring a single one in each genetic background. The IRRI-Japan collaborative project (FUKUTA et al., 2009) has further developed four universal differential variety sets, monogenic lines with Japonica type variety LTH genetic background and NIL's with three genetic backgrounds, $\mathrm{LTH}$, an indica type variety $\mathrm{CO} 39$ and a universal susceptible line, US-2. Several of these differential varieties are expected to contain minor or other major resistance genes that were additionally introduced from donor parents. Selection of differentials is very difficult when the resistance donors contain more than one resistance gene.
Even though, NIL's with a universal susceptible line US-2 genetic background will be more useful tool, they are still under development and may take some time to get pure lines. When they are available they can be used as genetic sources in breeding programs.

In a study with International Japanese and Korean differential sets Bonman et al. (1986) have shown that none of the agriculturally important Philippine isolates of $P$. grisea could be differentiated. The conventional differential sets and the expression of results as pathotype numbers did not yield useful information. According to these authors, for practical purpose in studies on the diversity of agriculturally important isolates of $P$. grisea, the use of widely grown local commercial cultivars as differential set is preferable to the conventional set of eight international differentials. Detailed investigations on pathogenic variability of $P$. grisea at Santa Rosa breeding site in Colombia have also shown that several pathotypes could be further differentiated into different pathotypes when local commercial cultivars were used as differentials (Correa-Victoria and Zeigler, 1993).

In China, detection of virulence changes in different populations of $P$. grisea was conducted by measurement of virulence frequencies to varieties planted in different areas (Li et al., 2005). Ji et al. (2009) developed complementary differentiating host varieties from regional varieties, to enhance the differentiating ability of national differential hosts. There were no distinct links between the pathotypes differentiated by two sets. But, it was possible to describe the evolution of virulence of $P$. grisea in Sichuan Province based on the virulence spectrum of individual local pathotypes, the sequential release of restorer lines and their resistance breakdown history.

In Brazil, a set of eight upland commercial rice cultivars was utilized as additional differentials for describing the virulence pattern of $P$. grisea. Utilizing Brazilian differentials the 14 isolates of pathotype IB-1 could be further classified into eight local pathotypes. Some of the Brazilian pathotypes that showed differential reaction on commercial rice cultivars such as Primavera and Maravilha could be utilized for incorporating resistance genes in susceptible cultivars using Brazilian pathoypes (Prabhu et al., 2002b). In a recent study for identifying pathotypes in upland rice, the Brazilian differentials showed greater differential ability than with the international differentials (SiLva et al., 2007). The virulence pattern of isolates of $P$. grisea from commercial fields of widely grown upland rice cultivars Primavera and BRS Bonança was tested by Araújo et al. (2005) on six newly released cultivars. These cultivars permitted to differentiate agriculturally important virulence in the pathogen population which can be utilized in selecting breeding lines for specific resistance in blast breeding program. Knowledge on the pathotype composition of the pathogen in commercial rice fields is important for rational 
deployment of resistance genes in breeding programs (CHen et al., 2001).

The irrigated rice breeding program for the State of Tocantins require information on the available resistance gene sources in commercial cultivars that offer resistance to local pathotypes. There is imminent need for selecting differential local cultivars to identify pathotypes occurring in the Tocantins State where approximately 50,000 hectares are annually grown under tropical flooded conditions. The present paper reports the use of cultivars adopted to local conditions as additional differentials and pathotypic diversity among the isolates retrieved from irrigated rice cultivars and conserved during 1994 to 2002.

\section{MATERIAL AND METHODS}

\section{Isolates}

Single conidial isolates of $P$. oryzae were obtained from sporulating lesions on leaves of commercial irrigated rice cultivars collected in farmers' fields in the municipalities of Duerê, Lagoa de Confusão, and Rio Formoso in Tocantins State. The Brazilian Pyricularia oryzae isolates collected during nine years (1994-2002) were maintained on sterilized filter paper discs in freezer at $-20^{\circ} \mathrm{C}$ in Pyricularia culture collection of Rice and Bean research center.

\section{Plant material}

The virulence frequency of isolates was tested utilizing 24 genotypes, including 16 commercial irrigated rice cultivars (BRS Chuí, Supremo, BRS Taim, BRS Atlanta, BRS Rio Formoso, Metica-1, Javaé, Epagri 108, Epagri 109, Cica-8, BRS Biguá, BRS Jaburu, Marajó, Jequetibá, BR IRGA-409 and BR IRGA-417) and eight international differentials (Raminad Str3, Zenith, NP 125, Usen, Dular, Kanto 51, Sha-tiao-tsao and Caloro). The test material was planted in plastic trays $(30 \times 15 \times 10 \mathrm{~cm})$ containing $3 \mathrm{~kg}$ of soil fertilized with NPK ( $5 \mathrm{~g}$ of 5-30-15 $+\mathrm{Zn}$ and $3 \mathrm{~g}$ of ammonium sulfate per $3 \mathrm{~kg}$ of soil). Twenty four cultivars were sown in two trays (10 to 12 seeds/cultivar) in $5 \mathrm{~cm}$ long rows.

\section{Plant inoculation and disease evaluation}

One hundred and ninety three isolates of $P$. oryzae were utilized in the present study. The multiplication and sporulation of the isolates for plant inoculation with conidial suspension was according to Filippi et al. (2002). A noninoculated tray containing international differentials was maintained as a check to ensure that no contamination had occurred at the time of inoculation. Inoculation tests were repeated twice or thrice until consistent and uniform reaction was obtained. Leaf blast was assessed 7 to 9 days after inoculation taking into consideration only two categories of reactions utilizing a 0 to 9 scale, where the lesion types 0,1 and 3 were considered resistant (incompatible) and 4 to 9 as susceptible (compatible) according to International Rice Research Institute (1988).

\section{Analysis}

The pathotypes were identified based on eight standard international differentials (ATKINs et al., 1967; LING and Ou, 1969). The virulence frequency of these isolates was based on similarity of reaction among the isolates. A binary matrix for the analysis of phenotypic virulence was created considering number 1 for compatible reaction and 0 for incompatible reaction for each isolate. A matrix of similarity between all pairs of isolates was constructed according to the coefficient of Jaccard. The data were utilized for calculating the coefficient of similarity using the unweighted pair-group method with arithmetic averages (UPGMA) employing the SAHN program of the Numerical Taxonomy and Multivariate analysis (RoHLF, 1993). The phenotypic diversity between populations was calculated according to year by using Margalef index (Margalef, 1958) by the formula $\mathrm{HM}=(\mathrm{r}-1) / \mathrm{In}(\mathrm{N})$ where $r=$ the number of distinct pathotypes detected and $\mathrm{N}=$ the number of isolates in the sample. Margalef index was used to detect the number of distinct pathotypes present indicating the great diversity in the populations using two sets of differentials. An approach similar to the one proposed by CHaO et al. (2009) was employed in order to estimate the values of alpha diversity of Margalef (MI). It represents the expected values and their respective confidence intervals at $95 \%$ of significance (MARGALEF, 1958). The richness of pathotypes observed $\left(S_{\mathrm{ob}}\right)$ was added to the number of pathotypes theoretically expected (A). Therefore the total of expected breeds $\left(S_{\text {te }}\right)$ will be equal to:

$$
S_{t e}=S_{o b}+A
$$

where:

$$
A=\left(\frac{m-1}{m}\right)\left(\frac{Q_{1}\left(Q_{1}-1\right)}{2\left(Q_{2}+1\right)}\right)
$$

and:

$Q_{1}=$ number of pathotype that occur with 1 individual

$Q_{2}=$ number of pathotype that occurs exactly with 2 individuals

$m=$ total number of individuals. 
Therefore:

$$
M I=\frac{\left(S_{t e}-1\right)}{\operatorname{Ln}(m)}
$$

The expected values of MI were estimated using the average of 20 thousand bootstrapping resamples (EFrON and Tibshirani, 1994) made in binary matrixes with dimensions $\left(m \times \mathrm{S}_{\mathrm{ob}}\right)$ and confidence intervals (CI) calculated by using the formula:

$$
C I=\left(\frac{\operatorname{Per}(0.975)-\operatorname{Per}(0.025)}{2}\right)
$$

where $\operatorname{Per}(x)$ is the percentiles of the 20 thousand values of bootstrapping of MI.

\section{RESULTS AND DISCUSSION}

The inoculation tests with 193 isolates using 16 irrigated rice cultivars showed wide differences in virulence frequency as shown in table 1 . The similarity coefficients in relation to phenotypic virulence ranged 0 to 0.9 to predominant pathotypes of $P$. oryzae, indicating differential reaction to some and similarity to others. For developing local cultivars for differentiating pathotypes occurring in tropical irrigated rice in Tocantins State, eight out of 16 commercial rice cultivars were selected based on the similarity coefficients, virulence frequency, genetic background and agricultural importance. The cultivars BR
IRGA-409, BRS Chuí, and Supremo exhibited similar reaction to great number of isolates. On the other hand, considering the reaction of BRS Biguá, in relation to BRS Chuí, Supremo, BRS Rio Formoso, Metica-1, Javaé, Epagri 109, and Epagri 108, the coefficients were low. Among the cultivars BRS Chuí, Supremo, and Atalanta, which showed high coefficient of similarity (> 0.85), Supremo was the one selected as differential based on high percentage of compatible isolates (41.2\%). Cultivar Supremo is a selection made from a Colombian genotype with unknown pedigree that was originally introduced from Colombia by Josepar Pelotas Company. The cv. BR IRGA-417 was selected as one of the differentials among the cvs. BR IRGA-409, BR IRGA-417 and Atalanta, which showed high similarity coefficient $(>0.73)$, whereas the cv. BRS Taim was selected based on its agricultural importance among the BRS Taim, Cica-8, and Marajó. The cultivar BRS Taim occupied approximately $90 \%$ of the total area cultivated corresponding to 72,000 ha during 1996-97 growing season. Currently, it is planted in 30.000 ha in the State of Mato Grosso do Sul and represents $50 \%$ of the area planted. It occupies second place in area planted in Tocantins State. The Metica- 1 was selected because of its high susceptibility to great number of isolates $(50.5 \%)$ to compliment international differential Shatiao-tsao and low similarity coefficient to 15 of 16 cultivars $(<0.37)$. The BRS Jaburu was selected to substitute Raminad str 3 which showed low compatibility (1.0\%) to majority of field isolates in Tocantins. The BRS Biguá also showed low coefficients of virulence to relatively higher number of isolates $(4.1 \%)$.

The frequency of isolates virulent to eight commercial rice cultivars selected as additional differentials ranged from $1 \%$ on BRS Jaburu to $50.5 \%$ on Metica-1, whereas

Table 1. Coefficients of similarity among 16 rice cultivars with compatible and incompatible phenotypic reaction, in inoculation tests

\begin{tabular}{|c|c|c|c|c|c|c|c|c|c|c|c|c|c|c|c|c|}
\hline Rice cultivars & 1 & 2 & 3 & 4 & 5 & 6 & 7 & 8 & 9 & 10 & 11 & 12 & 13 & 14 & 15 & 16 \\
\hline 1- BRS Chuí & 1 & & & & & & & & & & & & & & & \\
\hline 2- Supremo & 0.89 & 1 & & & & & & & & & & & & & & \\
\hline 3- BRS Taim & 0.23 & 0.21 & 1 & & & & & & & & & & & & & \\
\hline 4- BRS Atalanta & 0.85 & 0.85 & 0.02 & 1 & & & & & & & & & & & & \\
\hline 5- BRS Rio Formoso & 0.11 & 0.10 & 0.09 & 0.11 & 1 & & & & & & & & & & & \\
\hline 6- Metica-1 & 0.30 & 0.27 & 0.20 & 0.27 & 0.35 & 1 & & & & & & & & & & \\
\hline 7- Javaé & 0.01 & 0.01 & 0.07 & 0.01 & 0.02 & 0.09 & 1 & & & & & & & & & \\
\hline 8- Epagri-108 & 0.16 & 0.15 & 0.10 & 0.16 & 0.65 & 0.37 & 0.00 & 1 & & & & & & & & \\
\hline 9- Epagri-109 & 0.12 & 0.11 & 0.09 & 0.12 & 0.74 & 0.36 & 0.00 & 0.72 & 1 & & & & & & & \\
\hline 10- Cica-8 & 0.20 & 0.20 & 0.77 & 0.18 & 0.08 & 0.20 & 0.07 & 0.07 & 0.10 & 1 & & & & & & \\
\hline 11- BRS Biguá & 0.03 & 0.02 & 0.14 & 0.10 & 0.00 & 0.03 & 0.27 & 0.02 & 0.00 & 0.09 & 1 & & & & & \\
\hline 12- BRS Jaburu & 0.01 & 0.01 & 0.01 & 0.01 & 0.00 & 0.10 & 0.00 & 0.02 & 0.00 & 0.00 & 0.11 & 1 & & & & \\
\hline 13- Marajó & 0.23 & 0.22 & 0.71 & 0.20 & 0.08 & 0.22 & 0.07 & 0.06 & 0.09 & 0.84 & 0.10 & 0.01 & 1 & & & \\
\hline 14- BRS Jequitibá & 0.01 & 0.12 & 0.05 & 0.01 & 0.00 & 0.00 & 0.11 & 0.02 & 0.00 & 0.01 & 0.33 & 0.20 & 0.01 & 1 & & \\
\hline 15- BR IRGA-409 & 0.90 & 0.89 & 0.19 & 0.87 & 0.10 & 0.27 & 0.01 & 0.15 & 0.11 & 0.20 & 0.20 & 0.01 & 0.22 & 0.10 & 1 & \\
\hline 16- BR IRGA-417 & 0.73 & 0.71 & 0.15 & 0.75 & 0.11 & 0.25 & 0.01 & 0.18 & 0.13 & 0.15 & 0.02 & 0.01 & 0.19 & 0.00 & 0.79 & 1 \\
\hline
\end{tabular}
with 193 isolates $^{(1)}$

( $\left.{ }^{1}\right)$ Jaccard coeficient was calculated according to the following formula: $\mathrm{a} / \mathrm{a}+\mathrm{b}+\mathrm{c}$. Where $\mathrm{a}=$ virulent isolates for two cultivars. $\mathrm{b}$ and $\mathrm{c}=$ virulent isolates for one cultivar and avirulent for other and vice-versa. 
among standard set of international differentials the virulence ranged from $6.2 \%$ on Raminad Str3 to $87.0 \%$ on Sha-tiao-tsao (Table 2). The relative virulence frequency in both sets of differentials was considered as one of the criteria for selection of differentials. The genetic background of the selected Brazilian commercial cultivars was distinctly different. Care was taken to avoid cultivars with similar genetic background such as Epagri 108, Epagri 109 and BRS Rio Formoso. The Epagri 109 was selected as differential because it is still widely grown in the State of Tocantins.

For the identification and numbering of pathotypes occurring in Tocantins State the key for the identification of international pathotypes (LING and Ou, 1969) was adopted. The groups were designated as TA, TB, TC, TD, TE, TF, TG, TH and TI. The isolates of $P$. oryzae showing susceptible reaction on BRS Jaburu belong to TA group (128 reaction patterns) similar to the international group IA, and the numbers following the group letters indicate the pathotype number. Similar system was adopted for identifying Brazilian pathotypes in upland rice (PrABHU et al., 2002b).

The inoculation tests using eight international differentials showed that the pathotypes IB-45, IB-41, II-1, ID-13, IB-1 and IG-1 in descending order were predominant (Table 3 ). The pathotypes pertaining to group IB (31\%) were encountered in high frequency among isolates retrieved from commercial rice cultivars. By contrast, the pathotypes TI-1, TG-2, TD-15, TF-2, TB-64, TH-1, and TD-13 were identified in higher frequencies using local differential rice cultivars. Four pathotypes belonging to four different groups (TI-1, TG-2, TD-15 and TF-2) were predominant and represented by $53 \%$ of the isolates collected over years. These differential isolates are important than pathotypes identified using international set for incorporating specific resistance in widely cultivated commercial cultivars such as Epagri 109 and BR IRGA-417. The utility of using both sets was compared using the isolates collected in different years obtained from different commercial cultivars and experimental sites. Of 193 isolates tested it was possible to identify 38 pathotypes using international differentials and 29 pathotypes using the additional set of differentials. The two sets were complementary in detecting pathotypic variation.

Several pathotypes of importance can be identified from predominant pathotype IB-45 using additional local differential set (Table 4). These additional differentials do not substitute the standard international differentials but permit to identify pathotypes of local importance for breeding purpose. The pathotype IB-45 showed resistant reaction on Raminad Str3, NP125, Dular and Kanto 51, and susceptible reaction on four other differentials. This pathotype could be further classified into nine different pathotypes using local cultivars as additional differentials, the predominant once were TF-2 and TD-15. The pathotype TF-2 exhibited susceptible reaction on two of the additional differentials Epagri-109 and Metica-1 and resistant reaction to other six differentials. The unknown resistance genes form the other differentials can be selectively incorporated into the susceptible Epagri-109 using TF-2 by back cross breeding. The pathotype TD15 showed different reaction pattern exhibited susceptible reaction on BR IRGA-417 and Supremo, and resistant reaction on other six differentials. This pathotype is useful for resistance breeding of BR IRGA-417, and Supremo. The local differential set permitted to detect the presence of some unknown avirulence genes in the P. oryzae population, which were not distinguished by international set. The avirulence gene analysis is the best way to detect the corresponding vertical resistance genes in the host and should be considered for incorporation of resistance gene strategy.

Identification of cultivar specific isolates or local pathotypes is useful for inoculating $\mathrm{F}_{2}$ populations to select resistant plants in crosses using local cultivars. A triple cross of Epagri-109, BR IRGA-417, and BRS Biguá require two specific isolates exhibiting differential reactions on these cultivars. For example, TF-2 is compatible to Epagri 109 and

Table 2. Pathotype group, standard international differentials, virulence frequency, additional differentials, and their parents

\begin{tabular}{|c|c|c|c|c|c|}
\hline $\begin{array}{l}\text { Pathotype } \\
\text { groups }^{(1)}\end{array}$ & $\begin{array}{l}\text { International } \\
\text { differentials }\end{array}$ & $\begin{array}{l}\text { Virulence } \\
\text { frequency }^{(2)}\end{array}$ & $\begin{array}{l}\text { Additional } \\
\text { differentials }\end{array}$ & $\begin{array}{l}\text { Virulence } \\
\text { frequency }^{(2)}\end{array}$ & Parents of additional differentials \\
\hline A & Raminad Str 3 & 6.2 & BRS Jaburu & 1.0 & PDR/P3790//CT5746 \\
\hline B & Zenith & 50.3 & BRS Taim & 22.8 & Unknown \\
\hline C & NP-125 & 31.1 & BRS Biguá & 4.1 & Bluebelle/Pisari \\
\hline D & Usen & 68.4 & BR IRGA-417 & 32.0 & $\begin{array}{l}\text { NewRex/IR19743-25-2-2// BR IRGA- } \\
409\end{array}$ \\
\hline $\mathrm{E}$ & Dular & 18.7 & Javaé & 3.1 & $\begin{array}{l}\text { P } 3085 / / I R \text { 5853-118-5/IR 19743-25- } \\
\text { 2-2-3-1 }\end{array}$ \\
\hline $\mathrm{F}$ & Kanto 51 & 38.9 & Epagri 109 & 20.1 & CT 7347/IR 21015-72-3-3-3-1 \\
\hline G & Sha-tiao-tsao & 87.0 & Metica 1 & 50.5 & $\begin{array}{l}\text { IR 930-53. IR 579-160. IR 22. IR } \\
\text { 930-147-8. IR 930-31-10. IR } 662 . \\
\text { Colômbia } 1\end{array}$ \\
\hline $\mathrm{H}$ & Caloro & 86.5 & Supremo & 41.2 & Unknown \\
\hline
\end{tabular}

(1) The isolates which produce resistant reaction on all eight differentials pertain to the pathotype group I.

${ }^{2}$ The virulence frequency of isolates in percentage was based on number of compatible reactions in relation to total number of isolates tested. 
Table 3. Pathotypes of Pyricularia oryzae predominant in the State of Tocantins ${ }^{(1)}$

\begin{tabular}{|c|c|c|c|c|c|}
\hline $\begin{array}{l}\text { International } \\
\text { pathotype }\end{array}$ & Number of isolates & Percentage & Local pathotype & Number of isolates & Percentage \\
\hline IB-45 & 28 & 14.51 & TI-1 & 28 & 14.51 \\
\hline IB-41 & 21 & 10.88 & TG-2 & 27 & 13.99 \\
\hline II-1 & 19 & 9.84 & TD-15 & 24 & 12.44 \\
\hline ID-13 & 14 & 7.25 & TF-2 & 23 & 11.92 \\
\hline IB-1 & 11 & 5.70 & TB-64 & 17 & 8.81 \\
\hline IG-1 & 11 & 5.70 & $\mathrm{TH}-1$ & 13 & 6.74 \\
\hline IB-61 & 9 & 4.66 & TD-13 & 12 & 6.22 \\
\hline IC-13 & 9 & 4.66 & TB-41 & 7 & 3.63 \\
\hline IB-9 & 7 & 3.63 & TB-45 & 7 & 3.63 \\
\hline IC-9 & 7 & 3.63 & TB-61 & 4 & 2.07 \\
\hline IB-13 & 6 & 3.11 & TB-62 & 4 & 2.07 \\
\hline $\mathrm{IH}-1$ & 5 & 2.59 & TB-24 & 3 & 1.55 \\
\hline $\mid A-1$ & 4 & 2.07 & TB-63 & 3 & 1.55 \\
\hline ID-1 & 4 & 2.07 & TD-9 & 3 & 1.55 \\
\hline IF-1 & 4 & 2.07 & TB-13 & 2 & 1.04 \\
\hline IG-2 & 4 & 2.07 & TB-47 & 2 & 1.04 \\
\hline IB-37 & 3 & 1.55 & TG-1 & 2 & 1.04 \\
\hline IC-1 & 3 & 1.55 & TA-112 & 1 & 0.52 \\
\hline IA-65 & 2 & 1.04 & TB-32 & 1 & 0.52 \\
\hline IB-17 & 2 & 1.04 & TB-46 & 1 & 0.52 \\
\hline IB-33 & 2 & 1.04 & TB-54 & 1 & 0.52 \\
\hline ID-15 & 2 & 1.04 & TB-56 & 1 & 0.52 \\
\hline IA-125 & 1 & 0.52 & TC-24 & 1 & 0.52 \\
\hline IA-17 & 1 & 0.52 & TD-10 & 1 & 0.52 \\
\hline $1 \mathrm{~A}-45$ & 1 & 0.52 & TD-11 & 1 & 0.52 \\
\hline IA-69 & 1 & 0.52 & TD-14 & 1 & 0.52 \\
\hline IB-2 & 1 & 0.52 & TD-16 & 1 & 0.52 \\
\hline IB-57 & 1 & 0.52 & TD-7 & 1 & 0.52 \\
\hline IB-64 & 1 & 0.52 & TI-2 & 1 & 0.52 \\
\hline IC-21 & 1 & 0.52 & & & \\
\hline IC-25 & 1 & 0.52 & & & \\
\hline IC-29 & 1 & 0.52 & & & \\
\hline IC-45 & 1 & 0.52 & & & \\
\hline IC-5 & 1 & 0.52 & & & \\
\hline ID-10 & 1 & 0.52 & & & \\
\hline ID-6 & 1 & 0.52 & & & \\
\hline ID-9 & 1 & 0.52 & & & \\
\hline IE-1 & 1 & 0.52 & & & \\
\hline
\end{tabular}

(1) Number of isolates analysed $=193$

incompatible to BR IRGA- 417 , whereas TB- 41 is incompatible to BRS Biguá and compatible to both Epagri 109 and BR IRGA-417. These two specific isolates are required for artificial inoculations of $\mathrm{F}_{2}$ populations to select plants resistant to both these isolates. The local differentials give more useful information in relation to isolate cultivar interaction than international differentials.

The pathotypic diversity was studied using Margalef index beginning in the year 1994 (Figure 1). There was no decreasing or increasing trend but equally uniform with both differential sets. The population was phenotypically diverse, thus there was a relatively large number of pathotypes for given number of isolates. It is expressed in its simplest form as ratio of pathotypes to isolates $(\mathrm{r} / \mathrm{N})$ sampled. This measure is extremely sensitive to sample size since for detecting rare pathotypes a large sample is normally required. However, the past years data (sample size) was standardized by Margalef index and bootstrapping analyses (20 thousand runs) made in binary matrixes with dimensions $\left(m \times S_{\text {ob }}\right)$ and confidence intervals $(\mathrm{CI})$ (ChaO et al., 2009).

It is important to use both sets of differentials to monitor the virulence pattern of P. oryzae in tropical irrigated rice in Tocantins State. This information furnished by local cultivars as additional differentials will have predictive value in determining the rare pathotypes which pose a potential threat to the new released cultivars. The testing of advanced breeding lines using these pathotypes will also permit prediction of stability of resistance prior to commercial cultivar release. 
Table 4. Virulence pattern of isolates classified as pathotype IB-45 of Pyricularia oryzae on local rice differentials

\begin{tabular}{|c|c|c|c|c|c|c|c|c|c|}
\hline & A & B & C & D & $\mathbf{F}$ & E & G & H & \\
\hline Isolates $^{(1)}$ & $\begin{array}{c}\text { BRS } \\
\text { Jaburu }\end{array}$ & $\begin{array}{l}\text { BRS } \\
\text { Taim }\end{array}$ & BRS Biguá & $\begin{array}{c}\text { BR } \\
\text { IRGA-417 }\end{array}$ & Javaé & $\begin{array}{c}\text { Epagri } \\
109\end{array}$ & Metica-1 & Supremo & Pathotype $^{(3)}$ \\
\hline Рy778-96 & $\mathrm{R}^{(2)}$ & $\mathrm{S}^{(2)}$ & $S$ & $S$ & $\mathrm{R}$ & $\mathrm{R}$ & $S$ & $S$ & TB-13 \\
\hline Py5512-02 & $\mathrm{R}$ & S & $\mathrm{R}$ & $S$ & $\mathrm{R}$ & $S$ & $S$ & S & TB-41 \\
\hline Py5755-02 & $\mathrm{R}$ & $S$ & $R$ & S & $\mathrm{R}$ & $\mathrm{R}$ & $\mathrm{R}$ & S & TB-47 \\
\hline Рy5864-02 & $\mathrm{R}$ & $R$ & $R$ & $S$ & $\mathrm{R}$ & $\mathrm{R}$ & $S$ & $S$ & TD-13 \\
\hline Рy5950-02 & $\mathrm{R}$ & $\mathrm{R}$ & $\mathrm{R}$ & S & $\mathrm{R}$ & $\mathrm{R}$ & $\mathrm{R}$ & S & TD-15 \\
\hline Ру1165-97 & $\mathrm{R}$ & $R$ & $R$ & $S$ & $R$ & $\mathrm{R}$ & $\mathrm{R}$ & $S$ & TD-15 \\
\hline Py5781-02 & $\mathrm{R}$ & $\mathrm{R}$ & $\mathrm{R}$ & S & $\mathrm{R}$ & $\mathrm{R}$ & $\mathrm{R}$ & S & TD-15 \\
\hline Py5798-02 & $\mathrm{R}$ & $R$ & $R$ & $S$ & $R$ & $\mathrm{R}$ & $\mathrm{R}$ & $S$ & TD-15 \\
\hline Py5912-02 & $\mathrm{R}$ & $\mathrm{R}$ & $\mathrm{R}$ & S & $\mathrm{R}$ & $\mathrm{R}$ & $\mathrm{R}$ & S & TD-15 \\
\hline Рy5722-02 & $\mathrm{R}$ & $R$ & $R$ & $S$ & $R$ & $\mathrm{R}$ & $\mathrm{R}$ & $S$ & TD-15 \\
\hline Рy5920-02 & $\mathrm{R}$ & $R$ & $\mathrm{R}$ & S & $\mathrm{R}$ & S & $S$ & S & TD-9 \\
\hline Рy5511-02 & $\mathrm{R}$ & $R$ & $R$ & $R$ & $\mathrm{R}$ & $S$ & $S$ & $\mathrm{R}$ & TF-2 \\
\hline Py5607-02 & $\mathrm{R}$ & $R$ & $\mathrm{R}$ & $\mathrm{R}$ & $\mathrm{R}$ & S & S & $\mathrm{R}$ & TF-2 \\
\hline Рy5854-02 & $\mathrm{R}$ & $R$ & $\mathrm{R}$ & $\mathrm{R}$ & $\mathrm{R}$ & $S$ & $S$ & $\mathrm{R}$ & TF-2 \\
\hline Рy5644-02 & $\mathrm{R}$ & $R$ & $R$ & $\mathrm{R}$ & $R$ & S & $S$ & $\mathrm{R}$ & TF-2 \\
\hline Рy5591-02 & $\mathrm{R}$ & $\mathrm{R}$ & $\mathrm{R}$ & $\mathrm{R}$ & $\mathrm{R}$ & $S$ & S & $\mathrm{R}$ & TF-2 \\
\hline Рy5583-02 & $\mathrm{R}$ & $R$ & $R$ & $\mathrm{R}$ & $\mathrm{R}$ & S & $S$ & $\mathrm{R}$ & TF-2 \\
\hline Рy1689-99 & $\mathrm{R}$ & $\mathrm{R}$ & $\mathrm{R}$ & $\mathrm{R}$ & $\mathrm{R}$ & $S$ & $S$ & $\mathrm{R}$ & TF-2 \\
\hline Рy5662-02 & $\mathrm{R}$ & $\mathrm{R}$ & $\mathrm{R}$ & $\mathrm{R}$ & $\mathrm{R}$ & S & S & $\mathrm{R}$ & TF-2 \\
\hline Рy5669-02 & $\mathrm{R}$ & $R$ & $R$ & $R$ & $\mathrm{R}$ & $S$ & $S$ & $\mathrm{R}$ & TF-2 \\
\hline Рy5685-02 & $\mathrm{R}$ & $\mathrm{R}$ & $\mathrm{R}$ & $\mathrm{R}$ & $\mathrm{R}$ & $S$ & $\mathrm{~S}$ & $\mathrm{R}$ & TF-2 \\
\hline Рy2091-00 & $\mathrm{R}$ & $\mathrm{R}$ & $\mathrm{R}$ & $\mathrm{R}$ & $\mathrm{R}$ & $S$ & $S$ & $\mathrm{R}$ & TF-2 \\
\hline Рy2099-00 & $\mathrm{R}$ & $\mathrm{R}$ & $\mathrm{R}$ & $\mathrm{R}$ & $\mathrm{R}$ & $S$ & S & $\mathrm{R}$ & TF-2 \\
\hline Рy2148-00 & $\mathrm{R}$ & $R$ & $R$ & $\mathrm{R}$ & $R$ & $S$ & S & $\mathrm{R}$ & TF-2 \\
\hline Рy2885-01 & $\mathrm{R}$ & $\mathrm{R}$ & $\mathrm{R}$ & $\mathrm{R}$ & $\mathrm{R}$ & $S$ & $S$ & $\mathrm{R}$ & TF-2 \\
\hline Рy5734-02 & $\mathrm{R}$ & $R$ & $R$ & $\mathrm{R}$ & $R$ & $\mathrm{R}$ & $\mathrm{R}$ & S & $\mathrm{TH}-1$ \\
\hline Ру1237-97 & $\mathrm{R}$ & $R$ & $\mathrm{R}$ & $\mathrm{R}$ & $\mathrm{R}$ & $\mathrm{R}$ & $\mathrm{R}$ & $\mathrm{R}$ & TI-1 \\
\hline Py504-95 & $\mathrm{R}$ & $R$ & $R$ & $R$ & $\mathrm{R}$ & $\mathrm{R}$ & $\mathrm{R}$ & $\mathrm{R}$ & TI-1 \\
\hline
\end{tabular}

$\left.{ }^{1}\right)$ Accession number of $P$. grisea culture collection of Embrapa Rice \& Beans Center. Last two digits indicate the year of collection; ${ }^{(2)} \mathrm{R}=$ resistant reaction; $\mathrm{S}=$ susceptible reaction; ${ }^{(3)}$ Pathotypes were identified using eight commercial upland rice cultivars as additional differentials.

The classification and designation of plant pathogen population below species level as physiological races or pathotypes is studied in order to furnish germplasm with effective genes against prevalent pathotypes. The pathotype still continues to be an important phenotypic marker for characterizing $P$. oryzae population. It has great value for comparing the results of different investigators in relation to population diversity, originating from different cultivars, years, locations and regions based on the standard methods of identification.

The additional differentials complement the existing standard international differentials to enhance better understanding of the pathotype composition of the P. oryzae population occurring in the State of Tocantins. These diffetentials can also be used for studying pathotypes in other irrigated rice growing States in Brazil.

The main aspect of this study demonstrate that the virulence pattern of 28 isolates of pathotype IB- 45 was further differentiated into nine local pathotypes using additional differentials which has great agricultural importance. Similarily, another predominant pathotype IB-41 can be further classified into several pathotypes and identify resistance genes in the differentials for incorporating in widely grown commercial susceptible cultivars. The sample size varied from 4 to 58 in different years of collection and this study did not attempt to compare the populations in different years or changing pattern of virulence with time. Another aspect is the identification of the pathotypes occurring in low frequency using additional differentials. A very small proportion of isolates caused compatible reaction on cultivars BRS Jaburu, Javaé and BRS Bigua with virulence frequency varying from 1 to $4 \%$. The low virulence frequency in these cultivars showed that the resistance genes have not been widely used in this area or they have a wider spectrum of resistance. The isolates causing compatible reaction increase with the increase in area cultivated or change in aggressiveness of the blast isolates pertaining to the same pathotype (AHN, 2000). Further studies are required to monitor the changes in virulence of the existing isolates and pathotype diversity using these differentials.

Even though it is desirable to use the recently developed near isogenic lines, the NIL's developed also carry several minor and other major resistance genes (CHEN et al., 


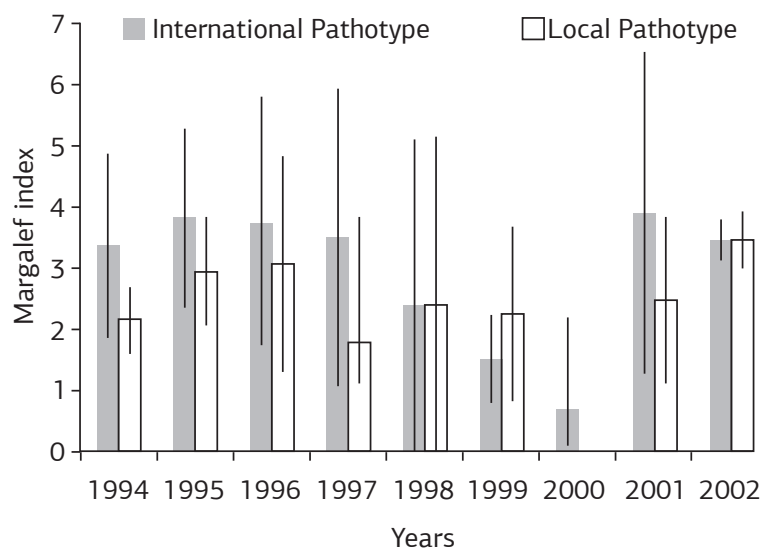

Figure 1. Margalef index for isolates of Pyricularia oryzae collected annually in Brazil from 1994 to 2002 and conserved in a culture collection of the EMBRAPA-Rice and Bean Research Center. Margalef index was used to detect the richness aspect of diversity among pathotypes. The numbers of isolates according to the years are: $1994=26 ; 1995=30 ; 1996=19 ; 1997=17 ; 1998=8$; $1999=14 ; 2000=4 ; 2001=17$; and $2002=58$. The bars are the confidence intervals $(\mathrm{p}>0.975)$.

2001; Fukuta et al., 2009). However, the validity of using additional differential hosts for monitoring virulence changes in the local cultivars with unknown resistance genes is not reduced. The importance was justified by the greater differential ability of the complimentary differentials developed in Sichuan in China than using national differential varieties (Ji et al., 2009).

Studies on genetic variability of $P$. oryzae using DNA markers showed that several distinct groups of pathogen population representing lineages exist in different regions. Some lineages consist of various pathotypes while others are represented by single pathotype. There was no straight relationship between lineages and pathotypes except few exceptions and require further study. In Colombia each lineage was associated with specific group of pathotypes (Chen et al., 1995). According to Ahn (2000) the combined use of pathotype and lineage would be more meaningful and value for application in resistance breeding. Further detailed investigations are required using molecular markers to characterize the pathotypes identified by the additional differentials.

The results from this study provided useful information for adopting desirable breeding strategy for the Tocantins State. These include diversification of resistance genes or incorporation of multiple resistance genes in the local highly productive and susceptible cultivars improved for grain quality.

\section{CONCLUSION}

Additional differentials of rice cultivars to identify $P$. oryzae pathotypes were detected. The $P$. oryzae pathotypes identified using the additional differentials can be used for selection and incorporating resistance genes in new rice cultivars in a breeding program.

\section{ACKNOWLEDGEMENTS}

We are grateful to Conselho Nacional de Desenvolvimento Científico e Tecnológico (CNPq) for granting a research fellowship to the first and seventh authors.

\section{REFERENCES}

AHN, S.W. Spatial and temporal stability of genetic resistance to rice blast. In: THARREAU, D.; LEBRUN, M.H.; TALBOT, N.J.; NOTTEGHEM, J.L. (Ed.). Advances in rice blast research. Dordrecht: Kluwer Academic Publishers, 2000. p.162-171.

ANJOS, L.M.; SANTOS, G.R.; DIAS NETO, J.J.; OLIVEIRA, W.F.; CASTRO NETO, M.D. Identificação de raças fisiológicas de Magnaporthe grisea em áreas de arroz irrigado no Estado do Tocantins. Tropical Plant Pathology, v.34, p.182-185, 2009.

ARAÚJO, L.G.; PRABHU, A.S.; SILVA, G.B. Virulence pattern of Pyricularia grisea isolates from farmers' fields on newly released upland rice cultivars. Fitopatologia Brasileira, v.30, p. 623-628, 2005.

ATKINS, J.G.; ROBERT, A.L.; ADAIR, C.R.; GOTO, K.; KOZAKA, T.; YANAGIDA, R.; YAMADA, M.; MATSUMOTO, $S$. An international set of rice varieties for differentiating races of Pyricularia oryzae. Phytopathology, v.57, p.297-301, 1967.

BONMAN, J.M.; DIOS, V.T.I.; KHIN, M.M. Physiologic specialization of Pyricularia oryzae in the Philippines. Plant Disease, v.70, p.767-769, 1986.

CHAO, A., COLWELL, R.K., LIN, C.; GOTELLI, N.J. Sufficient sampling for asymptotic minimum species richness estimators. Ecology, v.90, p.1125-1133, 2009.

CHEN, D.H.; ZEGLER, R.S.; LEUNG, H.; NELSON, R.J. Population structure of Pyricularia grisea in two screening sites in the Philippines. Phytopathology, v.85, p.1011-1020, 1995.

CHEN, H.L.; CHEN, B.T.; ZHANG, D.P.; XIE, Y.F.; ZHANG, Q. Pathotypes of Pyricularia grisea in Rice Fields of Central and Southern China. Plant Disease, v.85, p. 843-850, 2001.

CORREA-VICTORIA, F.J.; ZEIGLER, R.S. Pathogenic variability in Pyricularia grisea at a rice blast "hot-spot" breeding site in Eastern Colombia. Plant Disease, v.77, p.1029-1035, 1993.

EFRON, B.; TIBSHIRANI, R.J. An introduction to the bootstrap. Chapman \& Hall/CRC. 1994, 456p.

FILIPPI, M.C.; PRABHU, A.S.; ARAÚJO, L.G.; FARIA, J.C. Genetic diversity and virulence pattern in field populations of Pyricularia grisea from rice cultivar Metica-1. Pesquisa Agropecuária Brasileira, v.37, p.1681-1688, 2002.

FUKUTA, Y.; XU, D.; YANORIA, M.J.T.; HAIRMANSIS, A.; HAYASHI, N.; KOBAYASHI, N. Genetic characterization of 
universal differential variety sets developed under the IRRI-Japan collaborative research project. In: WANG, G.L.; VALENT, B. (Ed.). Advances in genetics, genomics and control of rice blast. Netherlands: Springer Science, 2009. p.325-335.

INTERNATIONAL RICE RESEARCH INSTITUTE (Los Baños, Philippines). Standard evaluation system for rice. Manila, 1988. 54p.

JI, H.; SHEN, L.; XIANG, Y.; ZHANG, Z.; LIAO, H; LUO, L.; QIN, Z.; PENG, Y. Studies on the complementary differential varieties and local physiologic races of Magnaporthe grisea in Sichuan Province. In: WANG, G.L.; VALENT, B. (Ed.). Advances in genetics, genomics and control of rice blast. Netherlands: Springer Science, 2009. p.229-238.

KOBAYASHI, N.; YANORIA, M.J.T.; TSUNEMATSU, H.; KATO, H.; IMBE, T.; FUKUTA, Y. Development of new sets of international standard differentials varieties for blast resistance in rice (Oryza sativa L.). Japanese Agricultural Research Quarterly, v.41, p.31-37, 2007.

LATTERELL, F.M.; TULLIS, E.C.; OTTEN, R.J.; GUBERNICK, A. Physiologic races of Pyricularia oryzae. Phytopathology, v.44, p.495-496, 1954.

\section{LEVANTAMENTO SISTEMÁTICO DA PRODUÇÃO} AGRÍCOLA. Rio de Janeiro: IBGE, v.16, p.1-82, 2004.

LI, J.; LI, C. CHEN, Y.; LEI, C.; LING, Z. Evaluation of twentytwo blast resistance genes in Yunnan using monogenetic rice lines. Acta Phytopathologica Sinica, v.32, p.113-119, 2005.

LING, K.C.; OU, S.H. Standardization of the international race numbers of Pyricularia oryzae. Phytopathology, v.59, p.339-342, 1969.

LING, Z.Z.; MEW, T.V.; WANG, J.; LEI, C.; HUANG, N. Development of near-isogenic lines as international differentials of the blast pathogen. International Rice Research Notes, v.20, p.13-14, 1995.

MACKILL, D.J.; BONMAN, J.M. Inheritance of blast resistance in near isogenic lines of rice. Phytopathology, v.82, p.746-749, 1992.
MARGALEF, R. Information theory in ecology. Gen. Systems. v.3, p. 36-71, 1958.

MEKWATANAKARN, P.; KOSITRATANA, W.; LEVY, M.; ZEIGLER, R.S. Pathotype and avirulence gene diversity of Pyricularia grisea in Thailand as determined by rice lines nearisogenic for major resistance genes. Plant Disease, v.84, p.60-70, 2000 .

OU, S.H. Pathogen variability and host resistance in rice blast disease. Annual Review of Phytopathology, v.18, p.167-187, 1980.

PRABHU, A.S.; FILIPPI, M.C.; ARAÚJO, L.G. Pathotype diversity of Pyricularia grisea from improved upland rice cultivars in experimental plots. Fitopatologia Brasileira, v. 27, p.468-473, 2002a.

PRABHU, A.S.; FILIPPI, M.C.; ARAÚJO, L.G.; FARIA, J.C. Genetic and phenotypic characterization of isolates of Pyricularia grisea from the rice cultivars Epagri 108 and 109. Fitopatologia Brasileira, v.27, p.566-573, 2002b.

ROHLF, F.J. NTSYS-pc: numerical taxonomy and multivariate analysis system. Version 1.80. New York: Exeter Software, 1993.

SILVA, G.B.; ZAMBOLIM, L.; PRABHU, A.S.; ARAUJO, L.G; ZIMMERMANN, F.J.P. Estimation of phenotypic diversity in field populations of Magnaporthe grisea from two upland rice cultivars. Fitopatologia Brasileira, v.32, p.005-012, 2007.

THINLAY; ZEIGLER, R.S.; FINCKH, M.R. Pathogenic variability of Pyricularia grisea from high- and mid-elevation zones of Bhutan. Phytopathology, v.90, p.621-628, 2000.

XIA, J.Q.; CORRELL, J.C.; LEE, F.N.; ROSS, W.J.; RHOADS, D.D. Regional population diversity of Pyricularia grisea in Arkansas and the influence of host selection. Plant Disease, v.84, p.877-884, 2000 .

YAMADA, M.; KIYOSAWA, S.; YAMAGUCHI, T.; HIRANO, T.; KOBAYASHI, K.; WATANABI, S. Proposal for a new method for differentiating races of Pyricularia oryzae Cavra in Japan. Annual Phytopathological Society of Japan, v.42, p.216-219, 1976. 